\title{
Trypsin Inhibitor Activity and Condensed Tannin Content in Bambara Groundnut (Vigna Subterranea (L.) Verdc) Grown in Southern Africa
}

\author{
*TIBE, O; AMARTEIFIO, J O; NJOGU, R M \\ Department of Basic Sciences, Botswana College of Agriculture, P/Bag 0027, Gaborone, Botswana. Tel: 267 3650104, Fax: 2673928753
}

\begin{abstract}
Legumes are an important source of protein in many developing countries. However this protein is not readily available because of antinutrients. Farmers are being encouraged to grow bambara groundnut to meet food sufficiency, hence information on the content of antinutrients is required. The objective of the study was to compare antinutrients trypsin inhibitor activity and condensed tannin content in nine landraces of bambara groundnut grown in three Southern African countries, Botswana, Swaziland and Namibia respectively. Trypsin inhibitor activity was determined in raw seeds using the method developed by Kakade et al. (1974). Six landraces from Namibia (AHM 968, NC2, NC1. DIP C and GAB C and AHM753), three from Swaziland (OM1, NC2 and UR/SR) and two from Botswana (DIPC and UR/SR) had high trypsin inhibitor activity. DIPC had the highest overall trypsin inhibitor activity (units/mg protein) of 60.4 while AHM 753 had low trypsin inhibitor activity of $49.1(\mathrm{p}<0.05)$. The trypsin inhibitor activity of each landrace differed from country to country with no simple pattern revealed but the landraces from Namibia had the highest activity and those grown in Botswana had the least. The trypsin inhibitor activity reported is higher than in soybean and pigeon pea. The condensed tannin content was determined using butanol-HCl method by Porter et al. (1986). It ranged from $0.02 \%$ in NC1 and OM1 grown in Swaziland and Namibia respectively to $0.49 \%$ in AHM 753 cultivated in Namibia. Thirteen out of the 27 samples analysed had tannin content below the allowed limit of $0.10 \%$; three were cultivated in Botswana and five each from Namibia and Swaziland. Seeds that had the highest condensed tannin content were brown, tan and red while those with the lowest condensed tannin content were cream coloured are they are recommended to be used in weaning formula. @JASEM
\end{abstract}

Legumes are an important source of protein in developing countries. There are many landraces of bambara groundnuts which are grown and consumed in Africa especially in the drought stricken countries like Botswana. Bambara groundnut (Vigna subterranea L. Verdc) is an important indigenous African edible legume, which is widely grown and consumed. Its name is derived from the name of a Mali tribe called "Bambara" (Linnemann and Azam Ali, 1993). Some are cooked in pods and eaten as a snack and seeds are cooked with samp and eaten as a main meal, and it takes $2-3$ hours to cook. In Botswana it is grown as an intercrop with cereal crops such as maize, sorghum and millet. It is rarely grown as a sole crop. This crop has diverse uses, providing nutritious food, animal fodder, and a source of income for the rural dwellers. Its edible seeds contain 18.0-24.0 \% protein and 42-70\% carbohydrate content (Adu-Dapaah et al. 2004; Amarteifio et al. 1997; Nwokolo, 1996; FAO, 1964). It also contains high lysine content which complements the low lysine content in cereals (Massawe et al. 2005). It fixes nitrogen in the soil through nodulation, and thus reducing the need for application of fertilizers (FAO, 1964). It is a drought, pest, disease resistant crop and it also reduces pests in the field. The digestion and bioavailability of the nutrients in the bambara seeds for animal and human nutrition is limited by antinutrients such as trypsin inhibitors and condensed tannins (Apata and Ologhobo, 1997). Condensed tannins (CTs) are polyphenolic substances widely distributed in plants, especially in legumes and due to their large structure are known to inhibit protein digestibility by forming irreversible complexes with proteins, thereby reducing the bioavalability of amino acids. However, recent research has also indicated that condensed tannins in low concentrations have beneficial effects in animal and human nutrition and health (Akindahunsi, 2005; Champ, 2002). The antinutrients are mainly located in the testa of legumes. Brown coloured seeds of cowpeas and Bambara groundnuts contain more tannins than the cream coloured (Nwokolo, 1996). Other antinutrients, such as trypsin inhibitors, inhibit the activity of digestive enzymes, haemaglutinnins inhibit the absorption of nutrients and phytates and oxalates bind to minerals. It is very essential to know the content of antinutrients and effective methods to inactivate them especially that Bambara seeds are used in weaning formula called "TSABANA" produced in Botswana (Ohiokpehai, 2003a). The present study therefore aims at investigating the levels of antinutrients trypsin inhibitors and condensed tannins present in Bambara 
groundnut landraces grown in Botswana, Namibia and Swaziland.

\section{MATERIALS AND METHODS}

The landraces investigated were AHM 968, AS17, OM1, NC2, NC1, DipC, Gab C, UR/SR, AHM 753 from Botswana, Swaziland and Namibia, respectively (Table 1) through an exchange of seed with Southern African partners. The seeds were ground using a coffee mill to a particle size of 20 mesh and defatted by mixing with five volumes of hexane $(w / v)$ for ten minutes. The mixture was filtered through Whatman No. 1 filter paper and the sediment rinsed with hexane three times to remove residual oil in the seed flour. The defatted flour was air-dried at ambient temperature until free of hexane odour. Trypsin inhibitor was extracted from the seed flour with a solution of $0.15 \mathrm{M} \mathrm{NaCl}$ in a ratio of $10: 1(\mathrm{w} / \mathrm{v})$ by shaking at $180 \mathrm{rpm}$ at ambient temperature for one hour. The mixture was centrifuged at $5000 * \mathrm{~g}$ for 30 minutes and the supernatant liquid saved. The trypsin inhibitor activity was determined by benzoyl-DLarginine-p-nitroanilide hydrochloride method as described by Kakade et al (1974). The data were subjected to the Analysis of Variance (ANOVA) and Duncan's Multiple Range test was used to separate the mean values $(p \leq 0.05)$.

Each sample $(200 \mathrm{mg})$ was taken in a glass beaker and $10 \mathrm{~mL}$ of $70 \%$ acetone was added. For each sample there were two duplicates. The beaker and the contents were suspended in an ultrasonic water bath
(Branson 3210) and subjected to ultrasonic treatment for $20 \mathrm{~min}$ at room temperature. The contents of the beaker were then transferred to centrifuge tubes and subjected to centrifugation for $10 \mathrm{~min}$ at approximately $3000 \mathrm{~g}$ at $4{ }^{\circ} \mathrm{C}$. The supernatant was collected and kept on ice ready for analysis.

Condensed tannin content was determined using butanol-HCl method (Porter et al. 1986) and absorbance readings taken using UV/VIS Spectrophotometer (Spectronic 20D Milton Roy) at $550 \mathrm{~nm}$.

Condensed tannin ( $\%$ dry matter) was determined using the leucocynadin equivalent formula: (A550nm $\times 78.26 \times$ dilution factor) $/ \%$ dry matter, where A550 nm is the absorbance of each sample. The data were subjected to the Analysis of Variance (ANOVA) and Duncan's Multiple Range test was used to separate the mean values $(\mathrm{p} \leq 0.05)$.

\section{RESULTS AND DISCUSSION}

The results for trypsin inhibitor activity and overall trypsin inhibitor are shown in Table 2 and 3 respectively. Apparently most of the landraces from Namibia had the highest trypsin inhibitor activity followed by Swaziland and lastly Botswana. The trypsin inhibitor activity ranged from 43.9 to 68.4 TIU/mg protein. NC2 from Namibia had the highest trypsin inhibitor activity while AHM753 from Swaziland had the lowest trypsin inhibitor activity.

\begin{tabular}{lll}
\multicolumn{2}{l}{ Table 1: Seed description of Bambara Groundnut landraces obtained from Botswana, Namibia and Swaziland } \\
\hline Landrace & Seed Description & Source \\
\hline AHM 968 & Tan testa, no eye & MAWRD, Namibia \\
AS 17 & Black stripes on cream background, brown irregular eye & MAWRD, Namibia \\
OM 1 & Cream testa, black butterfly-like eye & BCA, Botswana \\
Nyakeni Cream 2 & Cream testa, brown circular eye & UNISWA, Swaziland \\
Nyakeni Cream 1 & Cream testa, black triangular eye & UNISWA, Swaziland \\
Diphiri Cream & Cream testa, brown circular eye & BCA, Botswana \\
Gaborone Cream & Cream testa, black triangular eye & BCA, Botswana \\
UR/SR & Dark red, no eye & UNISWA, Swaziland \\
AHM 753 & Dark red testa, no eye, small medium seed size & MAWRD, Namibia
\end{tabular}

(Source: Karakari, S. K (2001)) 
There seem to be no obvious pattern in trypsin inhibitor activity of the landraces from the three countries. The results also indicate that there were some similarities and differences in trypsin inhibitor activities of landraces within a particular country. From the statistical analysis, the trypsin inhitor activity of OM1 from Swaziland was similar to that of NC2 from Swaziland $(p<0.05)$ but significantly different from other landraces. The trypsin inhibitor activity of AS17 from Namibia was similar to that of AHM753 from Namibia. For the landraces from Botswana, NC1 was similar to AHM968 $(\mathrm{p}<0.05)$. There were also some similarities and differences in trypsin inhibitor activity of landraces in different countries. AS 17 from Botswana was similar to AS17 from Namibia $(p<0.05)$ but significantly different from AS17 from Swaziland ( $>0.05)$. The trypsin inhibitor activity of DiPC from Botswana was similar to DiPC from Namibia. The means of the activity of each landrace in the three countries showed that $\mathrm{NC2}$ and DIPC had the highest activities and AHM 753 and AS 17 had the lowest. These results are found to be higher than those of Apata and Ologhobo 1997, who found trypsin inhibitor activities in two raw bambara varieties to be 9.4 and $12.2 \mathrm{TIU} / \mathrm{mg}$ protein. Linnemann and Azam-Ali (1993) reported that the trypsin inhibitor activity ranged from 6.75 to 15.44 $\mathrm{TIU} / \mathrm{mg}$ in $100 \mathrm{~g}$ samples from eight bambara genotypes. There is no correlation between the colour of the landraces and the trypsin inhibitor activity in this data.

Table 2: Trypsin Inhibitor Activity in units/mg protein (in triplicate)

\begin{tabular}{llll}
\hline Landrace & Botswana & Swaziland & Namibia \\
\hline AHM 968 & $54.6^{\mathrm{c}}$ & $53.5^{\mathrm{d}}$ & $62.6^{\mathrm{a}}$ \\
AS 17 & $51.8^{\mathrm{d}}$ & $44.4^{\mathrm{g}}$ & $51.6^{\mathrm{d}}$ \\
OM-1 & $57.1^{\mathrm{b}}$ & $66.9^{\mathrm{a}}$ & $46.1^{\mathrm{f}}$ \\
NC2 & $45.2^{\mathrm{g}}$ & $66.4^{\mathrm{a}}$ & $68.4^{\mathrm{a}}$ \\
NC1 & $54.0^{\mathrm{c}}$ & $56.5^{\mathrm{b}}$ & $58.3^{\mathrm{a}}$ \\
Dip C & $64.5^{\mathrm{a}}$ & $52.0^{\mathrm{d}}$ & $64.8^{\mathrm{a}}$ \\
Gab C & $57.1^{\mathrm{b}}$ & $50.9^{\mathrm{e}}$ & $60.3 \mathrm{a}$ \\
UR/SR & $58.3^{\mathrm{a}}$ & $62.4^{\mathrm{a}}$ & $54.8 \mathrm{c}$ \\
AHM 753 & $50.3^{\mathrm{e}}$ & $43.9^{\mathrm{g}}$ & $53.0 \mathrm{~d}$ \\
\hline
\end{tabular}

SAS Duncan's Multiple Range Test. Means with the same letter are not significantly different $p \leq 0.05$

There are no recommended FAO/WHO provisional standards to compare these results with. However, trypsin inhibitors are heat labile and are destroyed completely by wet heat (Apata and Ologhobo, 1997; Gurumoorth et al. 2003). The difference in activity could be due to different genotypes and environmental conditions such as soil fertility, climate, seasonality, rainfall and light intensity (Champ, 2002). The trypsin inhibitor activity is higher than in chickpea and pigeon pea. The trypsin inhibitor activity in pigeon pea ranged from 23.8$30.27 \mathrm{Tiu} / \mathrm{mg}$ protein (Fasoyiro et al. 2005) and chickpea ranged between 10.0-14.0 Tiu/mg protein (Apata and Ologhobo, 1997; Vistpanich et al. 1985). These results are also equal to and some higher than those of Gurumoorthi et al. (2003), who found the trypsin inhibitor activities of both black and white coloured accessions of Mucosa beans, South Indian pulses, ranging between 45.2 and 49.6 units $\mathrm{mg}^{-1}$ protein. These results would be useful to producers of animal feed which use raw materials.

Table 3: Mean of trypsin inhibitor activity (units/mg protein) for the landraces

\begin{tabular}{llllllllll}
\hline Landrace & $\begin{array}{l}\text { AHM } \\
968\end{array}$ & $\begin{array}{l}\text { AS } \\
17\end{array}$ & OM-1 & $\begin{array}{l}\text { NC } \\
2\end{array}$ & $\begin{array}{l}\text { NC } \\
1\end{array}$ & $\begin{array}{l}\text { Dip } \\
\text { C }\end{array}$ & $\begin{array}{l}\text { Gab } \\
\text { C }\end{array}$ & $\begin{array}{l}\text { UR/ } \\
\text { SR }\end{array}$ & $\begin{array}{l}\text { AHM } \\
753\end{array}$ \\
\hline Mean & \multirow{2}{*}{56.9} & 49.3 & 56.7 & 60.0 & 56.3 & 60.4 & 56.1 & 58.5 & 49.1 \\
& & & & & & & & & \\
\hline
\end{tabular}

The results of this study for the condensed tannins content of the nine Bambara landraces investigated are shown in Table 4 and 5. The CT content ranged from 0.041 to $0.493 \%$. AHM753 from Namibia had the highest content and was significantly different $(p>0.05)$ from the other landraces. The lowest content was found in OM1 from Namibia. There were some similarities and differences in $\mathrm{CT}$ content within a particular country. In landraces from
Botswana AS17, $\mathrm{NC1}$ and UR/SR the contents were similar $(\mathrm{p}<0.05)$ while in Namibia NC2, NC1, GabC and OM-1 were similar. AHM968 from Swaziland was significantly different from the other landraces $(p>0.05)$. The variation within the three countries AHM968, NC2, GabC and UR/SR were similar to those from Namibia $(p<0.05)$ and significantly different from those grown in Swaziland. AS17 and OM1 had similar content in the three countries 
$(\mathrm{p}<0.05)$. The results compare favorably well with those of Apata et al. (1997), who found the CT content in two bambara landraces to range from 0.37 to $0.39 \%$. Apata and Ologhobo (1997) also indicated that different processing methods such as cooking, roasting and autoclaving significantly reduced the tannin content in bambara groundnuts. Food processing is known to improve food quality and reduce some antinutritional factors (Ohiokpehai, 2003b). Removal of the antinutrients would be necessary for effective utilization of proteins, carbohydrates and minerals in human nutrition. Hence, CT content in cream landraces may not have an adverse effect on humans when the seeds are consumed. Bambara seeds are usually eaten mature or immature. However, in Botswana the common processing method for bambara groundnuts is boiling the seeds. Phenolic substances are leached in water as they are heat labile and cannot survive high temperatures. Dehulling, soaking, boiling and discarding of cooking water could also curtail the condensed tannin content (Champ, 2002; Nwokolo, 1997). Different processing methods such as wet and dry heat also need thorough investigations to determine if they are efficient in destroying the antinutrients. Dry heat is known not to be very efficient in eliminating the antinutrients. Cooking of bambara seeds may take two to three hours to cook and this has shown to be effective in reducing the tannin content (Apata and Ologhobo, 1997).

Table 4: Condensed tannin content as leucocyanidin equivalent (\%)

\begin{tabular}{llll}
\hline Landrace & Botswana & Namibia & Swaziland \\
\hline AHM 968 & $0.452^{\mathrm{a}}$ & $0.419^{\mathrm{a}}$ & $0.323^{\mathrm{b}}$ \\
AS 17 & $0.129^{\mathrm{d}}$ & $0.116^{\mathrm{d}}$ & $0.117^{\mathrm{d}}$ \\
OM-1 & $0.038^{\mathrm{f}}$ & $0.016^{\mathrm{f}}$ & $0.049^{\mathrm{f}}$ \\
NC2 & $0.060^{\mathrm{f}}$ & $0.042^{\mathrm{f}}$ & $0.086^{\mathrm{e}}$ \\
NC1 & $0.109^{\mathrm{d}}$ & $0.041^{\mathrm{f}}$ & $0.115^{\mathrm{d}}$ \\
Dip C & $0.133^{\mathrm{d}}$ & $0.060^{\mathrm{f}}$ & $0.044^{\mathrm{f}}$ \\
Gab C & $0.052^{\mathrm{f}}$ & $0.053^{\mathrm{f}}$ & $0.089^{\mathrm{e}}$ \\
UR/SR & $0.386^{\mathrm{b}}$ & $0.396^{\mathrm{b}}$ & $0.214^{\mathrm{c}}$ \\
AHM 753 & $0.372^{\mathrm{b}}$ & $0.493^{\mathrm{a}}$ & $0.225^{\mathrm{c}}$ \\
\hline
\end{tabular}

SAS Duncan's Multiple Range Test. Means with the same letter are not significantly different $p \leq 0.05$

The values of the CT content for the cream coloured landraces lie well below the recommended limit. The landraces with cream coloured testa (Table 1) had CT content less than $0.1 \%$. The maximum recommended limit of CT content in "Tsabana" is $0.1 \%$ (Ohiokpehai, 1994). In Botswana people prefer the cream coloured landraces for consumption than the tan, brown or black coloured landraces (Karikari, 2000). The black coloured landraces are associated with medicinal properties (Karikari et al. 1996). The values for the cream coloured landraces do not exceed the recommended limit of the CT content in Tsabana. The brown colored and red colored seeds had more CT content than the cream colored seeds $(\mathrm{p}>0.05)$. This data correlate well with the published data in the literature (Amarteifio et al. 1997). This is an indication that the CT content is concentrated in the seed coat, with trace amounts in the cotyledons, and this has been observed in cowpea varieties by Preet and Punia (2000). This pattern has also been observed in brown sorghum varieties which contained more CT content than white varieties (Amarteifio et al. 2003). There was no correlation between the colour of the eye of the seed and CT content. The difference and similarity in the CT content may be influenced by different cultivars, soil fertility, climate, seasonality, rainfall, light intensity, nutrient concentrations (Champ, 2002). Hybridization could also have an effect in the CT content. However, based on the results obtained it might not be significant. This was observed in the hybrid UR/SR seeds which had higher CT content. The CT content in Bambara landraces is lower than in other legumes such as cowpea (Asante et al. 2004) and pigeon pea (Fasoyiro et al. 2005). Asante et al. (2004) found the CT content in raw cowpea accessions to range from $0.12-2.38 \%$, pigeon pea by Fasoyiro et al. (2005) to range between $0.43-4.60 \%$ and soybean to be $0.33 \%$ (Visitpanich et al. 1985).

Table 5: Mean CT (\% leucocyanidin equivalent) for the landraces

\begin{tabular}{llllllllll}
\hline Landrace & AHM & AS & OM-1 & NC & NC & Dip C & Gab C & UR/ & AHM \\
& 968 & 17 & & 2 & 1 & & & SR & 753 \\
\hline Mean & 0.398 & 0.121 & 0.033 & 0.063 & 0.088 & 0.079 & 0.065 & 0.332 & 0.363 \\
\hline
\end{tabular}

Conclusion: There is no recommended maximum limit for the trypsin inhibitor activity. There seem to be no adverse effect of trypsin inhibitor activity in the landraces if consumed cooked but more research needs to be done. Landraces AHM968, AHM753, AS17 and UR/SR had CT content exceeding the 
allowed limit of $0.10 \%$ (Ohiokpehai, 1994) in all three countries and thus are of concern as they may inhibit protein digestion. The seeds with a cream coloured testa, DipC, GabC, NC1, NC2 and OM1 may be recommended to be used in weaning formula as the CT is within the allowed limit. From a nutritional perspective, these findings would assist farmers and consumers in Southern Africa to select for landraces with a high nutritive value but low CT and trypsin inhibitor content for cultivation and human consumption. Plant breeders should also look into producing landraces with reduced antinutritional factors as they impede the bioavailablity of minerals and protein digestibility. Further investigations need to be carried out to ascertain whether the CT content and trypsin inhibitors in bambara landraces would pose harmful effect on chickens and pigs if the ground seeds are used as animal feed.

Acknowledgement: The authors would like to thank European Union for financial assistance and Prof Karikari for providing the samples. Thanks to Dr. F. Wandera for assistance in statistical analysis of the data. We gratefully acknowledge B. Legwatagwata, T. Motlhabane and T.F Thema for technical assistance.

\section{REFERENCES}

Adu-Dapaah, HK; Sangwan, RS (2004). Improving bambara groundnut productivity using gamma irradiation and in vitro techniques. African Journal of Biotechnology 3(5), 260-265.

Akindahunsi, AA; Salawu, SO (2005). Phytochemical screening and nutrientantinutrient composition of selected tropical green leafy vegetables. African Journal of Biotechnology 4(6), 497-501.

Amarteifio, JO; Aganga, AA; Gabosekwe, J (2003). Chemical Composition of eight sorghum (Sorghum Bicolor (L) Moench) varieties grown in Botswana. Uniswa Journal of Agriculture 11, 22-27.

Amarteifio, JO; Karikari, SK; Modise, OJ (2002). The proximate and mineral composition of six landraces of Bambara groundnut. Tropical Science 42, 188-191.
Amarteifio, JO; Moichubedi, E (1997). Condensed tannin content in four landraces of Bambara groundnut. J. Agric. Trop. Subtro 98 [2], 139142.

Apata, DF; Ologhobo, D (1997). Trypsin inhibitor and other anti-nutritional factors in tropical legume seeds. Tropical Science 37, 52-59.

Asante, IK; Adu-Dapaah, H; Addison, P (2004). Seed weight and protein and tannin contents of 32 cowpea accessions in Ghana. Tropical Science 44, 77-79.

Champ, MMJ (2002). Non-nutrient bioactive substances of pulses. British Journal of Nutrition 88 (3), S307-S319.

FAO (1964). Legumes in human nutrition. FAO food and nutrition series no.19. Rome: Food and Agricultural Organisation, pp 115-116.

Fasoyiro, SB; Ajibade, SR; Saka, JO; Ashaye, OA; Obatolu, VA; Farinde, EO; Afolabi, OO (2005). Physical Characteristics and effects of processing methods on pigeon pea. Journal of Food, Agriculture and Environment 3 (3\&4), 59-61.

Gurumoorthi, P; Pugalenthi, M; Janaardhanan, K (2003). Nutritional Potential of Five accessions of a South Tribal Pulse Mucuna var utilis: Investigations on total free phenolics, tannins, trypsin and chymotrypsin inhibitors, phytohaemagglutinins and in vitro protein digestibility. Tropical and Subtropical Agroecosystems 1, 153-158.

Kakade, ML; Rackis, JJ; McGhee, JE; Puski, GA (1974). Determination of trypsin inhibitor activity of soy products: a collaborative analysis of an improved procedure. Cereal Chemistry 51, 376-382.

Karikari, SK (1996). The status of Bambara groundnut genetic resources in Botswana. SACCAR Newsletter 34-8, 16.

Karikari, SK (2000). Variability between local and exotic Bambara groundnut landraces in Botswana. African Crop Science Journal 8(2), 145-152. 
Karikari, SK (2001). Field Performance of Selected Bambara Groundnut (Vigna Subterranea (L.) Verdc Landraces). Proceedings of the MidProject Workshop held at the University of Swaziland, Kwaluseni Campus, 28-30 August. pp 28-30.

Linnemann, AR; Azam-Ali, SN (1993). Bambara groundnut (Vigna subterranean (L) Verdc). In: Pulses and vegetables (JT Williams, Ed), Chapman and Hall, London, 216-221.

Massawe, FJ; Mwale, SS; Azam-Ali, SN; Roberts, JA (2005). Breeding in Bambara Groundnut (Vigna subterranean (L.) Verdc. ): Strategic Considerations. African Journal of Biotechnology 4 (6), 463-471.

Nwokolo, E (1996). Bambara groundnut (Vigna subterranea). In: Food and Feed from Legumes and Oilseeds (E. Nwokolo and Smartt J, eds), Chapman and Hall, London, 216-221.

Ohiokpehai, O (2003a). Food Processing and Nutrition: A vital link in Agricultural Development. Pakistan Journal of Nutrition 2 (3), 204-207.
Ohiokpehai, O (2003b). Promoting the Nutritional Goodness of Traditional Food Products. Pakistan Journal of Nutrition 2 (4), 267-270.

Ohiokpehai, O; Jagow, J; Jagwer, J; Maruapula, S (1994). Tsabana-Towards locally produced weaning foods in Botswana. Paper presented at a Nutrition Security Workshop held in Gaborone, Botswana, 28-30 November.

Porter, LJ; Hrstich, LN; Chan, BG (1986). The conversion of procyanidins and prodelphinidins to cyanidins and delphinidins. Phytochemistry $25,223-230$.

Preet, K; Punia, D (2000). Proximate composition, phytic acid, polyphenols and digestibility (in vitro) of four brown cowpea varieties. International Journal of Food Sciences and Nutrition 51(3), 189-193.

Vistpanich, T; Batterham, ES; Norton, BW (1985). Nutritional value of chickpea (Cicer arietinum) and Pigeon pea (Cajanus Cajan) meals for growing pigs and rats. Energy content and protein quality. Australian Journal of Agricultural Research 36, 327-335 